\title{
RELIGIOUS VALUES IN BANGILUN DANCE VERSE AND ITS PEDAGOGICAL RELEVANCE TO CHARACTER BUILDING
}

\author{
Noviana Pusparini ${ }^{1 *}$; Muhammad Rohmadi²; Prasetyo Adi Wisnu Wibowo ${ }^{3}$ \\ ${ }^{1-3}$ Regional Language and Literature Education, Postgraduate Program, Sebelas Maret University \\ Jl. Ir. Sutami No. 36-A, Kentingan, Surakarta 57126, Indonesia \\ 'fimbrynoviana19@gmail.com; ${ }^{2}$ rohmadi_dbe@yahoo.com; 3 prasetyoadiwisnuwibowo@yahoo.co.id
}

Received: $19^{\text {th }}$ January 2021/ Revised: $31^{\text {st }}$ May 2021/ Accepted: $31^{\text {st }}$ May 2021

\begin{abstract}
How to Cite: Pusparini, N., Rohmadi, M., \& Wibowo, P. A. W. (2021). Religious values in Bangilun dance verse and its pedagogical relevance to character building. Humaniora, 12(3), 225-231.

https://doi.org/10.21512/humaniora.v12i3.6964
\end{abstract}

\begin{abstract}
The research aimed to describe and identify the religious value contained in the poetry of Bangilun dance and its pedagogical relevance. Religious values were character values related to divinity: they were the basis of thought, speech, and deed. This value could be found in traditions such as the Bangilun dance as a manifestation of local wisdom. The research applied a the descriptive qualitative method. Data in the research were Bangilun dance poems that contained religious values. The data sources were informants, Bangilun dance poetry notebooks, journals, and books related to the selected topic. Data collection was done by using documentation, observation, and interview techniques. Data analysis technique used the content analysis method. The results show that form of religious values found in Bangilun poetry is a form of human relationship with God, while the pedagogical relevance is the Bangilun dance poetry can be used as teaching material in schools by including it in all school activities (extracurricular and intracurricular), integrating it in all subjects at all levels of education, and cooperation of all elements (school, parents, and society).
\end{abstract}

Keywords: religious value, Bangilun dance, pedagogical relevance, character building

\section{INTRODUCTION}

Indonesia is a multicultural country with various tribes and races living together. Such fact is attributable to several factors, namely geographical, historical, and cultural permeability. Citizens' integrity is needed to maintain the country's unity. Many sources can be used to grow citizens' integrity. There are several functions in education, namely to develop capabilities and shape the character and civilization of the nation with dignity in the framework of educating the nation's life. One of the issues becoming a cause celebre recently is character building-based education. It is a systematic education process to provide explicit exposure of positive value in school with the purpose of building students' character. Several current studies have shown that holding character education. Research conducted by Kamaruddin (2012) has attempted to describe the significance of character education and its relationship with the social behavior, character-building process, social and personal value integration, character-based learning method, character-based learning draft, as well as its implementation and evaluation. The research has found that educational institutions do not only pay attention to students' academic achievement; rather, they also pay attention to their character development. With such kind of education, the students are expected to have adequate academic and character achievement. Several notions support the realization of character building in formal educational institutions, namely systematic and strategic planning and integrated program. However, there are several issues in character education need to pay attention to by the scientists, teachers, and stakeholders. It is as found by Hashim and Langgulung's (2008) research that aims to assess the Islamic education system in a Muslim country. In their research, there is a thesis that Islamic education greatly contributes to the development of world society; it is, 
therefore, worthy of studying it. However, according to findings, it is found that there are some points to improve and upgrade such as curriculum, learning facilities, administration, and financial management. There is some International Islamic education held to cope with that problem, such as Makkah (1977), Islamabad (1980), Bangladesh (1981), Jakarta (1982), and Cairo (1987). Another way to resolve the problem is by composing a sharing curriculum that can be used in Muslims. That curriculum is by all means in accordance with the international conference from Makkah to South Africa. The curriculum should pay attention to the notions of the meaningfulness of the method, pre-service teacher training, relevant textbook, and the recruitment of qualified teachers.

Building students' character is not only obtained from formal school-based education but also cultural heritage such as dance, fine art, ethno-music, and literature (Maknun \& Muzayanah, 2020). In Indonesia, several traditions heritage potentially build characters such as puppet shows, Ketoprak, and Ludruk. The roles of traditional arts as the source of teaching have invited many scholars to do some research. Research conducted by Saddhono and Pramestuti (2018) has tried to uncover the religious values in Javanese traditional poem (Tembang Macapat) entitled Pocung. According to this research, it is found that the poem contains plenty of religious value. The word pocung in the title is a Javanese word referring to a corpse or body dressed up with a white cloth. With regard to its cultural as well as philosophical meaning, it symbolizes the spiritual clearance of a dying man. With such a spiritual condition, it is expected that God may forgive all the sins and bless him with great happiness hereafter. Besides, this poem provides several teachings of Islam and reflects Javanese local wisdom. It is revealed that the ideal Javanese people are those religious and civilized.

Burhanudin (2017), in research, has tried to uncover the religious values in a heritage building of an Islamic monarchy, including Makam Kota Tinggi (tomb), Masjid Syahabuddin (mosque), Ruang Pertemuan Kesultanan (ballroom), and Makam Sultan Abdul Jalil Muzafar (Tengku Suang Asmara) (the Sultan's tomb) situated in Mampura. The religious values in each building are delivered through calligraphies in each building. Those calligraphies contain the identity of the royal family, the identity of the buildings (the year when it was built), some verse of prayer, some verse of the Quran, the Prophet's name and his family as well as his friends.

Research conducted by Freeman (2014) has described the use of storybooks as the means to teach kindergarten students (4-6 years old) anti-bullying attitudes. The treatment takes 12 weeks, and it results in satisfactory. According to the questionnaire, it is found that the students have a better understanding of bullying attitudes after getting the treatment. Overall, their opinion represented by the questionnaire shows that students recognize bullying (physical and mental) as a bad attitude. It is, therefore, none of them willing to commit it.

Research conducted by Suwarno, Saddhono, and Wardani (2018) has described the history, cultural elements, and character education values found in a folktale entitled Sungai Naga. According to the research, it is found that the origin of a river, socalled Sungai Naga, is taken from the legend's main character, Gerdu. He is a powerful man that banished a dragon passing the river. The findings reveal three cultural elements found in the legend, namely cognition system, the system of technology, living equipment system, and religious system. Furthermore, there are three education character values: working hard, religious value, and environmental care value.

Amid the dynamic change of civilization, the existence of traditional art is relatively well preserved due to its flexible development. From the perspective of pedagogy, traditional arts as one of the cultural products play a significant role as one of the sources to build characters. However, it seems to be only well theorized. In reality, most of the traditional arts (dance, puppet show, Javanese theatre) pay more attention to the aspect of aesthetics as the means to deliver entertainment. As a result, the innovation is more on the artistic side of those traditional arts.

One of the well-preserved traditional art is Jaranan Turangga Yakso from Trenggalek. It is thanks to the innovation of choreography and cinematic innovation (Wisang, 2019). Meanwhile, it seems that the innovation on the notion to deliver the local wisdom in those traditional arts pays less attention. As a matter of fact, local wisdom is the key term to cope with character-building problems (morality, religion, and nationalism). Local wisdom refers to a system of collective cognition followed by a community to maintain harmony, humanism, and dignity. It is recorded in any verbal and non-verbal expression, and it is hereditarily obtained (Saddhono \& Pramestuti, 2018). As a result, the audiences are only impressed with its aesthetic aspect; they only regard it as an entertainment performance. It then leads to some misunderstanding toward some traditional arts, such as an old verse written by Sunan Kalijaga entitled Lingsir Wengi. The massive misunderstanding toward that verse makes many Javanese people presume that the verse is a supra-natural spelling to communicate with the devil. Even though the macapat songs are actually a cultural product that has noble values. This is confirmed by Juniarti, Saddhono, and Wibowo (2019), who say that the macapat song actually contains high moral values. Another case is the misunderstanding on a song entitled by Lathi by Genius Weird. That song is the object of suspicion on supra-naturalism just because Javanese, in some part its refrain. It seems that Javanese, especially the canonic Javanese, is oftentimes associated with mysticism even by the native speakers of Javanese. It is by all means not the purpose of that verse. The verse of Bangilun dance as a traditional verse from Temanggung is another case of a traditional verse facing a massive misunderstanding in society. It is stigmatized as a heretical ritual. It is 
even associated with supra-natural activity. In fact, the Bangilun dance and the accompanying contains plenty of religious values. It is not only a traditional dance performance but also a preaching activity. According to preliminary research, it is found that some of the lines in the accompanying verse talk about some religious teachings. Therefore, the current research aims to uncover the religious values hidden behind the accompanying verse of Bangilun traditional dance.

\section{METHODS}

The research applied a qualitative descriptive method with a focus on descriptions and narratives in presenting findings. The descriptive method is one of the methods in research that is designed descriptively. It tries to describe and analyze any situation or phenomenon as an object of research with the theory and skills of the researcher as an analytical tool (Musfah, 2016). Data in the research are in the form of Bangilun dance verses. Sources of data are (1) documents, namely in the form of Bangilun dance verse notes, journals, and books relevant to the research); (2) informants including Bangilun dance artists, art experts, and teachers.

Data collection techniques include observation, interviews, and documentation. Observations are made by making direct observations and recording interesting things in the Bangilun dance performance. Then the interview technique is carried out by the researcher using dialogue or questions and answers to informants. Types of interviews conducted by researchers are in-depth interviews and structured-non-structured interviews. In-depth interviews are conducted to obtain information from informants in an in-depth, problemfree, and focused manner. Structured interviews are carried out by preparing instruments in advance so that researchers can get the required information precisely and accurately. Meanwhile, a non-structured interview is an interview that is conducted without preparing the instrument beforehand; the aim is that the researcher gets complete and complete information. The documentation technique is carried out by recording and transcribing the verses of the Bangilun dance so that the content and flow of the Bangilun dance verses are obtained completely. After that, the verse of the Bangilun dance is carried out in the selection and classification process. The validity of the data in this research uses triangulation techniques, including theory, sources, and methods. Theory triangulation is carried out using various theories to examine research problems so that complete conclusions can be drawn and their validity can be tested. Source triangulation is carried out using a variety of different sources to obtain oral data from informants. Method triangulation is done by collecting similar data but with different techniques so that the information stability can be tested. Data analysis technique is a content analysis that aims to get valid conclusions and can be retested according to the context. The stages include data reduction, data presentation, and drawing conclusions. The data reduction stage aims to sharpen the data, classify the data according to the research objectives, and focus the data on the main and important things. The data are then analyzed to be classified according to research objectives, namely religious values and pedagogical relevance in schools. The presentation of data is the stage of compiling data to be presented in a clear and systematic manner so that data is easier to interpret with relevant theories. Drawing conclusions or verification is the final analysis carried out by analyzing data related to certain symptoms in the field. After that, the data verification is done, whether it is correct, accurate, and valid, so that it can be accounted for.

\section{RESULTS AND DISCUSSIONS}

One form of art that contains local wisdom values in the Kledung area of Temanggung regency is the Bangilun dance. The word Bangilun is short for $B$ (udaya), A (liran), $N$ (enek moyang), $G$ (erak), $I$ (ndah), L (estari), $U$ (ntuk), $N$ (asional). The people of Kledung themselves interpret the word Bangilun as pengilon. The word pengilon means mirror; the point is that humans always reflect or introspect themselves throughout their life. Humans should always be selfaware that, in fact, they are forgetful beings who are never free from mistakes. Bangilun is also an acronym for bengi-bengi tebangan ing alun-alun (shalawatan nights in the square). This acronym implies that the Bangilun dance is performed in the square or wide field accompanied by prayer because this dance requires a large enough distance to accommodate a large number of personnel. Whereas the only large area that Kledung Village had in the past was a field or square. In its development, now the Bangilun dance is not only held in a large field but is performed on a stage wide enough to accommodate the dancers and their accompanists.

Shalawat as a dance accompaniment shows that the Bangilun dance is not only a dance that presents a spectacle but can also be used as a guide. Moreover, the verse contains a lot of noble teachings, such as macapat. This is confirmed by Juniarti, Saddhono, and Wibowo (2019), who say that the macapat song actually contains high moral values. The teachings contained in the Bangilun dance verse include mutual cooperation, harmony, nationalism, Pancasila, religion, and so on. Bangilun dance verse has been written by artists from the Sri Lestari studio since 1959. To date, the collected Bangilun dance verse has reached 120 passages using the Javanese language of the ngoko variety.

The research studies the religious value contained in the verse of the Bangilun dance. Through a closed reading on it, it is found that the verse provides a profound moral value. Value is defined as a concept to build mental; it is formulated through attitude. Furthermore, it is a regulative standard of 
attitude and preference (in term of social relations and future goals) (Mustari \& Rahman, 2011). This is confirmed by Sulaksono et al. (2019), who say that religious values are related to individual beliefs in God's existence and teachings. There are at least fiveelement guiding people to religiosity, namely religious belief, worship, religious knowledge, religious experience, and changes of the four elements (Stark \& Glock, 1968). According to the analysis, it is found that there are six religious values found in the verse of Bangilun dance. Based on its dimensions, the religious values contained in the Bangilun dance verses discuss the relationship between humans and their God. The following are teachings based on religious values in Bangilun dance verses.

First, the Bangilun dance verse teaching only prays to Allah (God). It is found that there are several prayers written in verse. Those prayers are performed before the performance; they are about harm avoidance, asking for mercy, asking for Bangilun performance sustainability, and asking for the country unity. The prayer performed before the performance is written in the first line of the verse Bismillahirrahmanirrahim anyebut kang nguwasani jagad iki, pambukane seni Bangilun Sri Lestari (In the name of The Almighty God, The Master of the Universe. May Bangilun Sri Lestari performance blessed). The second line is the expression to ask for harm avoidance "Mugi-mugi paringa langgeng lestari, ana bilahi saka kulon baliya ngulon, ana bilahi saka lor baliya ngalor" (May God keep us away from any harm). The prayer to ask for God's mercy is written in the third line, "Keparenga pareng rohmat, dhuh Allah lestariya, kamardikan wus sanyata, wusana wosing pangidung, tarlen amung amemuji, mugi-mugi bangsa kita, mugi kersa amanunggal, gumeleng gelenging kapti" (O God, we beg for your mercy. O Almighty God, we beg for the unity and sustainability of our country). Those prayers are not only addressed to the artists of Bangilun dance but also for the unity and sustainability of the country where they live in. It implies that the artist of Bangilun dance is concerned with the notion of nationalism and identity. Such phenomenon gives a positive contribution to the civic. According to Drolet and Morris in Blank and Schmidt (2003), the national identity reflects a subjective emotional relationship as the fundamental element in a civic. With regard to the finding, the presented concept might be fit some points. However, the finding demonstrates that cultural values also give a positive contribution to the notion of national identity. The awareness of national identity can potentially generate patriotic spirit. It then gives a positive impact on student competitiveness.

Second, the Bangilun dance verse teaches to perform Salah (Islamic Obligatory Prayer). Another religious value revealed in the verse of Bangilun dance is the teaching to perform Salah as written in line 20, "wis lunggguha cah ayu ning wangkon mami, padha wungu, lunga kali padha wudhu, tekan kali kancane wis dha ngenteni, mangkat subuh ning mushola wis dha lungguh, dha pujian ngenteni sing dadi imam " $(\mathrm{O}$, my beautiful girl gets up and perform the dawn prayer. Recite the holy words while waiting for the priest to lead the prayer). Prayer is a form of worship that begins with performing Takbir and ends with a greeting reading the prayers according to the predetermined terms and conditions. Prayer is the main obligation for Muslims after the creed. Yasyakur (2017) has stated that prayer is a pillar of religion that is a disaster of faith because it is regulated with the heart, spoken orally, and carried out with actions. Therefore, prayer has an essential rank, namely as a pillar of religion, an obligation that is determined directly through the Isra' Mi 'raj event, the main and first obligation to be judged in the hereafter, the main and foremost obligation among other practices, and to differentiate between Muslims and infidels. In addition, Salah does not only teach religious values.

Salah does not only teach religious values. There are several other values explicitly or implicitly taught in salah, such as being disciplined, being hygienic. It teaches discipline because a Muslim must be punctual in performing obligatory daily Salah (five times a day). Salah teaches to be hygiene, for it is a must to wash the face, hands, and feet before performing it. Furthermore, it teaches solidarity and a spirit of unity through a collective Salah (jam'ah). According to AlQur'an, performing collective Salah is 27 times much better instead of the individual Salah. Such teaching is actually the fundamental nature of being a social creature. The spirit of unity and solidarity is actually one of the natures of Indonesia. It is reflected in the most popular proverb, gotong royong (referring to mutual cooperation), performed through direct social contact. Drolet and Morris (2000) have said that one possible facilitator of mutual cooperation is face-toface contact. There are several positive impacts from mutual cooperation, namely improving productivity, saving time, and lightening the job.

Third, the Bangilun dance verse teaches to read and recite Al-Qur'an. There are several lines that indicate it, "sun wiwiti, lha kitab iki, sedaya persun Bangilun punsami ngaji, kitab Quran dadi panuntun, dadi panuntun seniman lan seniwati, murid iki guyub lan rukun, terus dibangun Bangilun ning Desa Kledung" (The artists of Bangilun dance in Kledung village have read Al-Qur'an for many. They read it to learn virtue. Let us read Al-Qur'an for the guidance). Al-Qur'an is a holy book revealed to the Prophet Muhammad PBUH to guide men in this mortal world. Hariandi (2019) has said that the Al-Quran is the word of God which is revealed to the Prophet Muhammad in stages through the intercession of the Jibril and has the value of worship as if he reads it. There are several notions in it, such as rituals, the history of the previous holy book. Furthermore, it tells the story of several great humble, honest, religious peoples in the past. Those positive characters can be the best source to build the character of today's Muslims in this disruptive era. Such character is not restricted to some period of time and civilization. It is important to instill such character for a better generation. Another verse 
teaching to read and learn Al-Qur'an is in line - 31, "ayo kanca dha mara ning papan gunung, minggah gunung tumekane Gunung Tidar, mula kabeh lampahe sing ngati-ati, padha sesuci lan padha ngaji." (Let's climb the Tidar. No need to be careless. Climb it right away that we can learn and read the Qoran). Reading and learning Al-Qur'an is compulsory for Muslims; there is guidance to the right morality. Furthermore, there is a blessing promised for those performing it. Given the importance of reading the Al-Quran, Rasulullah PBUH advises his people to provide lessons to read the Al-Quran to children since they were young because at that time there is a large and strong learning potential (Hamdani, 2017).

Fourth, the Bangilun dance verse teaches about the five pillars of Islam. Besides providing teachings to perform prayer (du'a), perform Salah, and recite Al-Qur'an, several lines in Bangilun provide teaching about five pillars of Islam, "sampurnane wong urip iku angawruhi yaiku ageme gesang, ingkang lelima iku wernane, Rukun Islam yaiku agama suci" (there are five things to do for the perfection of a Muslim life namely). They proclaim Syahadah (a Muslim creed), perform Salah, perform fasting in Ramadhan, perform zakat (a Muslim charity), and perform haj to those who can afford it. Syahadah, as the part first Islamic principle, teaches a Muslim to be consistent either in their deeds or words; the inconsistency will lead to hypocrisy. Then Salah teaches a Muslim to be disciplined, to be polite, to be hygienic, to be wise, and to be sympathetic. Fasting teaches Muslims to control their eagerness and emotion. Moreover, it does our health good. Fasting also teaches a Muslim always to be grateful. Zakat teaches a Muslim to be generous. Haj teaches a Muslim about solidarity as in the Haj ritual; all the pilgrims must wear the same color and mode of cloth. Such teaching reflects that a Muslim should not be mundane; God does not take the materials into account instead of the spiritual and heart. It implies that there is no superiority. Overall, all those Islamic principles teach humankind to have a good attitude, morality, and ethics. For those notions distinguish man from other creatures. The better morality, attitude, and ethics will lead to a better life for a Muslim (Abdullah, 2007).

Fifth, the Bangilun dance verse teaches about God's traits. There are several lines that provide teaching for a Muslim to recognize and remember God's principle natures consistently. One of them is in the line 54, "Allah wujud, kidam, baqa', mukhalafatul lilhawaditsi, qiyamuhu binafsihi, wahdaniyah, qudrat, iradat, ilmun, hayat, sama', basar, kalam, qadiran, muridan, aliman, hayyan, sami'an, bashiran mutakaliman." (Allah is, kidam, baqa', mukhalafatul lilhawaditsi, qiyamuhu binafsihi, wahdaniyah, qudrat, iradat, ilmun, hayat, sama', basar, kalam, qadiran, muridan, aliman, hayyan, sami'an, bashiran mutakaliman). This stanza reveals the qualities of God that explain God is immanent, immortal, and omnipotent. In Islamic tradition, recognizing God's qualities is part of Tawhid study (a discipline in
Islamic study concerned with God's recognition). For a Muslim, it is important to recognize God's qualities for better spiritual quality. For they are aware that there is God who observes every single deed performed. The analogy is that a super auditor is keeping an eye on the employee for twenty hours. Such sense has a positive implication for character building, such as honesty, discipline, and responsibility.

Sixth, the Bangilun dance verse teaches to perform Prophet Muhammad PBUH prayer (shalawat). Another religious value in verse is the teaching to perform Prophet prayer. It is as written in the line53, "Dhuh Gusti Pangeran kula, mugi-mugi Paduka pareng pahargyan, dhumateng panutan kita, inggih Njeng Nabi Muhammad, dalah sakulawarganya, sami manggiha raharja." (O Almighty God. We beg you blessing our Prophet and his family). Performing Prophet prayer is one the compulsory for a Muslim and try to imitate every single deed $\mathrm{He}$ (the Prophet) and follow every single deed of the Prophet. There is a guarantee from God for the Muslim willing to raise prayer for the Prophet and imitate his deed. According to some Muslim scholars such as Imam Ghazali, Imam Nawawi, Imam Tirmidzi, Syich Nawawi Al-Bantani, Sycih Hashim Ashari, there are some benefits obtained from performing Prophet prayer (shalawat). Shalawat may lead to the peaceful spiritual that upgrades the faith quality as well as life quality.

Global competition is inevitable in this 4.0 Industrial revolution era. It is imperative for the stakeholders to upgrade the human resource for better competitiveness. Building character is one of the fundamental issues in realizing the qualified generation (Poerwopuspito, 2010). Supriyono, Wardani, and Saddhono (2018) have stated that character values are scales that can determine a person's good or bad behavior. Virtuous ethics is one of the character constituents that might come from religious values supported by cultural values. This is confirmed by Tyas and Kuswarsantyo (2018), who says that the value of character education can be obtained from cultural arts, which can bind the nation and strengthen community solidarity.

There are several processes in building character, one of them is through education. This education can be obtained by students through formal and non-formal schools (Rohmadi \& Saddhono, 2014). Education-based character building is a process of humanity value transformation amid the dynamic life of civil society in a country (Sukiyat, 2020). Rokhman, Hum, and Syaifudin (2014) have stated that education is the best media to build the human resource of a nation. It is important then for the government to strengthen character-building based on education. For it is an effort to educate the students by instilling moral value. It is expected that the student can make proper decisions and practice the value in their daily life so that they become patriotic, productive, and virtuous citizens (Suwarno, Saddhono, \& Wardani, 2018). Character education or moral teaching has the aim of overcoming the moral decline that has recently 
been happening (Wahid \& Saddhono, 2017). This is confirmed by Karmini (2020), who says that character education aims to shape students' personalities. Astuti, Waluyo, and Rohmadi (2019) have revealed that the value of character education is a program that harmonizes culture, environment, and society. The character-building process can be integrated into the curriculum for familiarization in the students' daily life. It gives students have a better understanding of the aspects of cognitive, affective, moral feeling, and action. Furthermore, such an education model makes students have better cognition, affection, moral feeling, moral action, and improved psychomotor (Suprapto, 2014).

Generally, there are three steps in the agenda of character building. The initial stage emphasizes the student's awareness of a series of lives that have consequences and responsibilities. The relationship stage emphasizes the process of independent learning to socialize with others and develop sensitivity. The final stage is the development of a graduate profile according to the expected educational standards (Kamaruddin, 2012). Characters development through those three steps always refers to a character value. Saddhono and Erwinsyah (2018) have stated that there are 18 characters values that should be taught, namely religiosity, honesty, tolerance, discipline, working hard, creativity, self-reliance, democracy, curiosity, nationalism spirit, patriotism, sense of appreciating, friends, peacefulness, reading enthusiasm, environmental care, social care, and responsibility.

Concerning the findings, it is found that there are some notions of paying attention to hold a character education, namely educational institution management, curriculum, media, and source. The research on the verse of Bangilun dance is not only for the purpose of the documentation of heritage tradition but also as a proposal to make use of the verse as the source of Javanese teaching material, especially to the competence of Javanese performance analysis (see Permendikbud No 67/68/69/70 2013). The documentation of the Bangilun dance is one of the efforts to preserve it. The research findings have revealed that the verse of the Bangilun dance contains plenty of religious and moral values. In relation to the character education notion, the preservation of Bangilun dance supports its realization. There are several ways to realize it, namely: (1) inserting the value of character education in all school activities (extra-curricular or intra-curricular); (2) integrating the character education program to all subjects and all levels of education (elementary level to tertiary); (3) the collaboration of all elements (school, parents, and society). Furthermore, the government is expected to be more active in realizing the character education program by issuing more regulations and developing the existing regulation to realize a more advanced character education.

Bangilun dance is one of the traditional dances from Temanggung, accommodating plenty of characters' value. Religiosity is one of the character's values emphasized in the verse of the dance. Those religious characters' values are to perform prayers only to the Almighty God, perform Salah, recite and read Al-Qur'an, recognize five pillars of Islam, God quality recognition, and perform Prophet Prayers (shalawat). Those religious characters are found to build the students' characters positively. It, therefore, needs to be supported with the proper teaching material. According to the curriculum of 2013, it is programmed that there is basic competence to analyze Javanese art performance for the second-year student of SMA (High School). With regard to that curriculum demand, it is imperative for the teachers to choose the Javanese art performance containing the character values matching with the surrounding society. The religious values found in Bangilun dance might be the source to give character education.

\section{CONCLUSIONS}

The results show that, first, the form of religious values found in the Bangilun dance is a form of the human relationship with God. Second, its pedagogical relevance is that Bangilun dance poetry can be used as teaching material in schools by including it in all school activities (extracurricular and intracurricular), integrating it in all subjects at all levels of education, and cooperation of all elements (school, parents, and society). Religious values are important to be instilled in schools because they will help students use their knowledge and study to develop social skills that allow the development of noble morals and apply them in everyday life.

The limitation of the research focuses on an in-depth analysis of the religious values contained in Bangilun dance poetry and has not yet analyzed other noble values. Thus, the limitations of research can open opportunities for further research on Bangilun syair dance. Other noble values can be found so that Bangilun dance poetry can be maximally utilized to manage character education based on local wisdom in schools.

\section{REFERENCES}

Abdullah, M. Y. (2007). Studi akhlak perspektif Al-Quran. Jakarta: Amzah.

Astuti, R. W., Waluyo, H. J., Rohmadi, M. (2019). Character education in animation movie of "Nussa Rarra". Budapest Intenational Research and Critics Institute-Journal (BIRCI-Journal), 2(4), 215-219. https://doi.org/10.33258/birci.v2i4.610.

Blank, T., \& Schmidt, P. (2003). National identity in a united Germany: Nationalism or patriotism? An empirical test with representative data. Political Psychology, 24(2), 289-312. https://doi.org/10.1111/0162895X.00329.

Burhanuddin, D. (2017). The religious meaning of Islamic inscription in Kota Tinggi cemetery, Siak, Riau 
province. Heritage of Nusantara: International Journal of Religious Literature and Heritage, 6(1), 65-90. http://dx.doi.org/10.31291/hn.v6i1.404.

Drolet, A. L., \& Morris, M. W. (2000). Rapport in conflict resolution: Accounting for how face-to-face contact fosters mutual cooperation in mixed-motive conflicts. Journal of Experimental Social Psychology, 3(6), 26-50. https://doi.org/10.1006/jesp.1999.1395.

Freeman, G. G. (2014). The implementation of character education and children's literature to teach bullying characteristics and prevention strategies to preschool children: An action research project. Early Childhood Education Journal, 42(5), 305316. http://dx.doi.org/10.1007/s10643-013-0614-5.

Hamdani, M. (2017). Penerapan metode membaca Alquran pada TPA di kecamatan Amuntai Utara (Studi pada metode iqra dan metode tilawati). Al-Qalam: Jurnal Ilmiah Keagamaan dan Kemasyarakatan, 11(24), 89-106. http://dx.doi.org/10.35931/aq.v0i0.12.

Hariandi, A. (2019). Strategi guru dalam meningkatkan keterampilan membaca Alquran siswa di SDIT Aulia Batanghari. Jurnal Gentala Pendidikan Dasar, 4(1), 10-21. https://doi.org/10.22437/gentala.v4i1.6906.

Hashim, C. N., \& Langgulung, H. (2008). Islamic religious curriculum in Muslim countries: The experiences of Indonesia and Malaysia. Bulletin of Education \& Research, 30(1), 1-9.

Juniarti, A. P., Saddhono, K., \& Wibowo, P. A. W. (2019). Religious values in kitab Kalam Qodrat manuscript as literary heritage. Seword Fresh, 1(1), 1-8. https:// doi.org/10.4108/eai.27-4-2019.2286803.

Kamaruddin, S. A. (2012). Character education and students social behavior. Journal of Education and Learning, 6(4), 223-230.

Karmini, N. N. (2020). Pendidikan karakter dalam cerita rakyat Rajapala. MUDRA: Jurnal Seni Budaya, 35(1), 22-29. https://doi.org/10.31091/mudra. v35i1.994.

Maknun, M. L., \& Muzayanah, U. (2020). Contextualization of Suluk Candra's character values. Heritage of Nusantara: International Journal of Religious Literature and Heritage, 9(1), 1-51. https://doi. org/10.31291/hn.v9i1.563.

Musfah, J. (2016). Tips menulis karya ilmiah: Makalah, penelitian, skripsi, tesis \& disertasi. Jakarta: Kencana.

Mustari, M., \& Rahman, M. T. (2011). Nilai karakter: Refleksi untuk pendidikan karakter. Yogyakarta: Laksbang Pressindo.

Poerwopoespito, F. O. S. (2010). Menggugah mentalitas profesional \& pengusaha Indonesia. Jakarta: Grasindo.

Republik Indonesia. (2013). Peraturan Menteri Pendidikan dan Kebudayaan Indonesia tentang kerangka dasar dan struktur kurikulum Sekolah Dasar/Madrasah Ibtidaiyah. Jakarta: Sekretariat Negara.

Rohmadi, M., \& Saddhono, K. (2014). Novel "Bidadaribidadari Surga" karya Tere Liye dalam rangka pembentukan generasi Indonesia yang unggul. Karsa, 22(1), 82-92. https://dx.doi.org/10.19105/ karsa.v22i1.546.
Rokhman, F., Hum, M., \& Syaifudin, A. (2014). Character education for golden generation 2045 (National character building for Indonesian golden years). Procedia-Social and Behavioral Sciences, 141, 11611165. https://doi.org/10.1016/j.sbspro.2014.05.197.

Saddhono, K., \& Erwinsyah, H. (2018). Folklore as local wisdom for teaching materialsin Bipa program (Indonesian for foreign speakers). $K n E$ Social Sciences, 3(10), 444-454. http://dx.doi. org/10.18502/kss.v3i10.2926.

Saddhono, K., \& Pramestuti, D. (2018). Sekar macapat pocung: Study of religious values based on Javanese local wisdom. El Harakah: Jurnal Budaya Islam, 20(1), 15-32. https://doi.org/10.18860/ el.v20i1.4724.

Stark, R., \& Glock, C. (1968). Patterns of religious commitment: Volume 1 (American piety: The nature of religious commitment). California: University of California Press.

Sukiyat, S. (2020). Strategi implementasi pendidikan karakter. Surabaya: Jagad Media Publishing.

Sulaksono, D., Wibowo, P. A. W., Wardani, H. K., Kamal, S. F., \& Saddhono, K. (2019). Educational values Ludruk story 'Tragedi Kebun Tebu' made by Cak Edy Karya. Incolwis, 1(1), 1-7. https://doi. org/10.4108/eai.29-8-2019.2288947.

Suprapto. (2014). Revolusi mental dimulai dari pendidikan. Surabaya: Unika Darma Cendikia.

Supriyono, S., Wardani, N. E., \& Saddhono, K. (2018). Nilai pendidikan karakter sajak 'Bulan Ruwah' karya Subagio Sastrowardoyo dalam pembelajaran sastra. Scholaria: Jurnal Pendidikan dan Kebudayaan, 8(2), 120-131. https://doi.org/10.24246/j.js.2018. v8.i2.p120-131.

Suwarno, S., Saddhono, K., \& Wardani, N. E. (2018). Sejarah, unsur kebudayaan, dan nilai pendidikan karakter dalam Legenda Sungai Naga. RETORIKA: Jurnal Bahasa, Sastra, dan Pengajarannya, 11(2), 194-203. https://doi.org/10.26858/retorika. v11i2.5972.

Tyas, G. P., \& Kuswarsantyo. (2018). Nilai pendidikan karakter dalam ragam gerak tari Serimpi Pandelori. MUDRA: Jurnal Seni Budaya, 33(2), 182-190. https://doi.org/10.31091/mudra.v33i2.329

Wahid, A. N., \& Saddhono, K. (2017). Ajaran moral dalam lirik lagu dolanan anak. MUDRA: Jurnal Seni Budaya, 32(2), 172-177. https://doi.org/10.31091/ mudra.v32i2.107.

Wisang, A. M. (2019). Cultural co-modification of Jaranan Turangga Yakso dance in Jaranan Festival Intrenggalek region. Journal of Advances in Social Science and Humanities, 5(1), 555-561. https://doi. org/10.15520/jassh51394.

Yasyakur, M. (2017). Strategi guru Pendidikan Agama Islam dalam menanamkan kedisiplinan beribadah sholat lima waktu. Edukasi Islami: Jurnal Pendidikan Islam, 5(9), 1185-1230. http://dx.doi.org/10.30868/ ei.v5i09.86. 